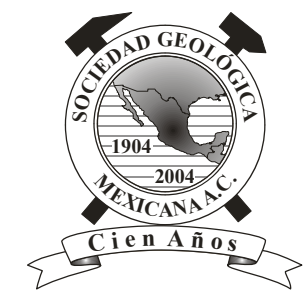

\title{
The origin of life from a paleontological perspective, a review
}

\author{
Catalina Gómez-Espinosa ${ }^{1, *}$, María Colín-García ${ }^{2}$, Alicia Negrón-Mendoza ${ }^{3}$ \\ ${ }^{1}$ Facultad de Ciencias, Universidad Nacional Autónoma de México, Circuito exterior S/N, Ciudad Universitaria, 04510 México, D.F., \\ México. \\ ${ }^{2}$ Instituto de Geología, Universidad Nacional Autónoma de México, Ciudad Universitaria, 04510 México, D.F., México. \\ ${ }^{3}$ Instituto de Ciencias Nucleares, Universidad Nacional Autónoma de México, Circuito exterior S/N, Ciudad Universitaria, 04510 \\ México, D.F., México. \\ *c_gomez@ciencias.unam.mx
}

\begin{abstract}
Although the origin of life cannot be dated with precision, life must have appeared soon after the cooling of the Earth, when the existence of liquid water on the planet enabled primitive oceans to exist. In fact, fossil records support the evidence of life on Earth earlier than $3400 \mathrm{Ma}$ ago. In order to understand the origin of life, it is useful to track geochemical factors such as the presence of carbon and isotopic evidence, which also suggests the presence of microbials. Eoarchean crustal rocks are located on Akilia Island and on the Isua Greenstone belt southwest of Greenland. The oldest recognized microfossil record is 3430 Ma old from Strelley Pool Formation cherts, Pilbara, Australia. In Paleontology, it is necessary to reevaluate the outcrops of the oldest rock in light of new technologies, new techniques, and a multidisciplinary approach. This will help support data about when life emerged.
\end{abstract}

Keywords: Earliest microfossils, Eoarchean, Paleoarchean, ancient life, biosignatures.

\section{Resumen}

Aunque no puede decirse con precisión cuando se originó la vida en el planeta hay evidencia de que ocurrió poco después de que la Tierra se enfrió, cuando las temperaturas permitieron la existencia de agua líquida y el desarrollo de la hidrosfera primitiva. El registro fósil aporta datos de que la vida existió mucho antes de los 3400 Ma. Para entender el origen de la vida se ha recurrido al estudio de trazas geoquímicas analizando la presencia de carbono orgánico y a la evidencia isotópica que sugieren actividad microbiana. La corteza litosférica más antigua, que data del Eoarqueano, se encuentra en la isla de Akilia y en el cinturón Isua Greenstone al suroeste de Groenlandia, pero el microfósil más antiguo proviene de pedernal de la Formación Strelley Pool en Pilbara, Australia, con una edad de 3430 Ma. En el campo de la Paleontología es necesario reevaluar los afloramientos del Eoarqueano y Paleoarqueano utilizando las nuevas tecnologías desde una perspectiva multidisciplinaria para aportar datos respecto a cuando ocurrió el origen de la vida.

Palabras clave: Microfósiles más antiguos, Eoarqueano, Paleoarqueano, vida antigua, biofirmas.

\section{Introduction}

The formation of the Earth has been calculated to have occurred 4600 Ma ago (Schopf, 1992) while the oldest known zircon, from the Earth's original solid rock crust has been dated at $4.374 \mathrm{Ma}$ (Valley et al., 2014). The analysis of molecular clocks indicates that Archaea and Eubacteria were probably present on Earth at least $4000 \mathrm{Ma}$ ago (Battistuzzi and Hedges, 2009). On the other hand, the oldest true fossil is $3400 \mathrm{Ma}$ old and was discovered in sandstone at Strelley Pool in Western Australia (Wacey et al., 2011). Lazcano and Miller (1994) calculated more than 10 Ma between the 
evolution of the first DNA/protein systems and the presence of cyanobacteria.

Elucidating when life originated on Earth is not an easy task and Altermann and Kasmierczak (2003) consider there to be three ways to search for evidence of ancient life on Earth during the Archean period: biomarker detection, microfossils, and biosedimentary structures. However, even if all these approaches are considered, it is still very difficult to obtain reliable data about the precise time when life arose. This is because fossil records are scarce. In this article, the oldest fossil records reported are reexamined and compared in order to trace the existence of the first living beings from a paleontological point of view. The debate is still going on, but new evidence and information from the field is presented for a better understanding of the origin of life.

\section{The fossil record and the oldest life forms}

The paleontological record has provided the timescale for tracking evolutionary history. It supports the idea that the origin of life occurred earlier than $3400 \mathrm{Ma}$ ago, corresponding possibly to sulphur-metabolizing microbe cells (Philipot et al., 2007). Those cells were complex enough to suggest that more primitive cells must have existed before. Based on highly debatable radioisotopic data, it has been suggested that life started at $4200 \mathrm{Ma}$ (Nemchin et al., 2008).

The establishment of the earliest record of life (in the form of microfossil, chemical fossils and/or organosedimentary structures) needs to take into account the nature of the hydrosphere and the atmosphere during the Archean when life emerged, and during the evolution of primitive life (Awramik and Grey, 2005).

It is generally assumed that the emergence of life required the presence of liquid water (Westall, 2005). This condition was fully satisfied because water was available since the accretion of the Earth, and the most accepted model suggests that water was delivered by carbonaceous chondrites and comets (Dauphas et al., 2000). In addition, geological evidence in the form of zircon crystals from the Hadean age (4300 - $4400 \mathrm{Ma})$ at Jack Hills, Yilgarn Craton, Western Australia (Wilde et al., 2001), suggests the activity of low temperature hydrothermal fluids. Russell and Hall (1997) estimate that between $4200-4100 \mathrm{Ma}$ ago, the surface temperature of the Earth was approximately $90^{\circ} \mathrm{C}$; this temperature was low enough to allow the existence of liquid water on the surface.

Very little is known about the environments in which life may have arisen. A variety of habitats were available from the deep ocean floor to subaerial environments (Westall, 2005). Traditionally, it has been assumed that life emerged in shallow marine-marginal environments (Javaux et al., 2010). However, a deep-sea origin of life has also been suggested, taking black smokers as a model (Philippot et al., 2007). This last proposal adds the possibility that the earliest microbial life could have been sulphur-based biota (Wächtershäuser, 1992). Recently, one of the most accepted of theses proposals suggests that life arose in an environment similar to the actual alkaline hydrothermal vents found in the Lost City hydrothermal field (Boetius, 2005; Lane et al., 2010).

Nevertheless, another question arises if one postulates that life emerged out of the oceans: how was the first ocean formed, evolved and composed? Lacking solid evidence, there has not been an available and accepted model of how the terrestrial oceans were formed (Pinti, 2005).

Most controversies about the hydrosphere are focused on its chemical parameters, including the $\mathrm{pH}$ and salinity of marine water. There is currently no consensus regarding the pH of primitive oceans. Kempe and Degens (1985) proposed an alkaline pH; Grotzinger and Kasting (1993) and Pinti (2005) considered an acid pH; and Holland (1984) suggested a neutral environment. Two propositions can be identified in the discussion of the primitive ocean's marine salinity: that it was higher than today (de Ronde and Ebbessen, 1996) and that it was similar to today or had a normal salinity (35 ppt) (Touret, 2003). In conclusion, little can be said about the composition, $\mathrm{pH}$ and salinity of primitive oceans.

In regard to the Earth's primitive atmosphere, it is suggested that it must have been dusty and thick due to high volcanic activity and constant meteorite bombardment (Westall, 2005). Atmospheric composition is still a matter of discussion, but it was most definitely oxygen depleted (Farquhar, 2003).

One paleontological principle, called "uniformitarianism," assumes that "the present is the key to the past," a phrase attributed to James Hutton in the 1790s. However, during the Archean, most planetary processes were considerably different from the ones today, including the composition of the atmosphere (lower $\mathrm{O}_{2}$, higher $\mathrm{CO}_{2}$ ) and hydrosphere (higher $\mathrm{Fe}^{2+}$ ) (Holland, 1984); the tectonic rates (higher flow thought the crust) (Mojzsis and Harrison, 2000); a high meteorite bombardment; the solar cycles (Antcliffe and McLoughlin, 2008); and the fact that there were shorter days and higher tides (Westall, 2005). In light of these facts, Archean paleobiology must be interpreted in a different way for decoding the signals of earliest life

\section{Eoarchean and Paleoarchean signatures of life: sedimentary microbial structures and chemical evidence.}

In order to understand the origin of life, it is useful to track the geochemical and isotopic evidence of biological past processes that could possibly have been preserved in minerals resistant to metamorphism. This geochemical evidence is considered a signature of life, or biosignature (Steele et al., 2006).

The major differences between chemical and biochemical systems, according to Sharma (2005), include: the ability of replication from one generation to another; the presence 
of complex molecules and enzymes, the essentials of living systems; and the existence of a membrane that delimits and separates the cell from the external environment.

Recent efforts in the study of ancient life signatures are focused on the distinctions among true fossil remains and abiotic structures that can potentially be formed during hydrothermal processes. This is one of the most interesting topics in the study and characterization of life (Oehler et al., 2008). The application of techniques such as Raman spectroscopy has made possible the identification of biosignatures in extreme environments. This procedure has the advantage of recording data from both geological and biological components (Edwards et al., 2011).

Eoarchean crustal rocks are located in Akilia Island and the Isua Greenstone belts southwest of Greenland (Westall, 2005; Schopf, 2006) (Figure 1). Based on an analysis of carbon isotopes taken from graphite inclusions in apatite grains, researchers have claimed the existence of early evidence of life in rocks within a banded iron formation (BIF) on Akilia Island ( $3850 \mathrm{Ma})$; graphite inclusions contain ${ }^{13} \mathrm{C}$, which can be correlated with biological activity (Mojzsis et al., 1996). Further geochemical studies demonstrate that the outcrops considered to be BIFs correspond to a metasomatized ultramafic igneous protolith. In one of these studies, two possible abiotic mechanisms for the generation of graphite are proposed (Fedo and Whitehouse, 2002). The debate over the interpretation of the Akilia rocks continues into the present day, although the sedimentary chemical origin of the BIFs was claimed again and supported by studies of iron isotopes (Dauphas et al., 2004). Another possibility is that the BIF could have originated from a seawater derivation; this was suggested and interpreted as a parallel to the existence of modern mid-ocean ridge hydrothermal vents (Dauphas et al., 2007). This finding was rebutted, however, after the reexamination of new apatite samples, as well as the study of original crystals. Petrographic studies by means of optical microscopy and scanning electron microscopy (SEM), combined with energy-dispersive spectrometry from apatite samples, could not definitively find evidence of any graphite inclusion in these samples (Lepland et al., 2005). This lack of graphite was supported by a petrographic study of 92 apatite samples (Nutman and Friend, 2006). Nevertheless, the controversy around this record continues: McKeegan et al. (2007) claimed they had unearthed ancient evidence of life, as well as the presence of graphite, in the Akilia samples using Raman confocal spectroscopy. However, new studies again refuted the presence of the world's oldest biosignatures on Akilia. Applying U-Pb analytical methods and isotopic data, it was demonstrated that the

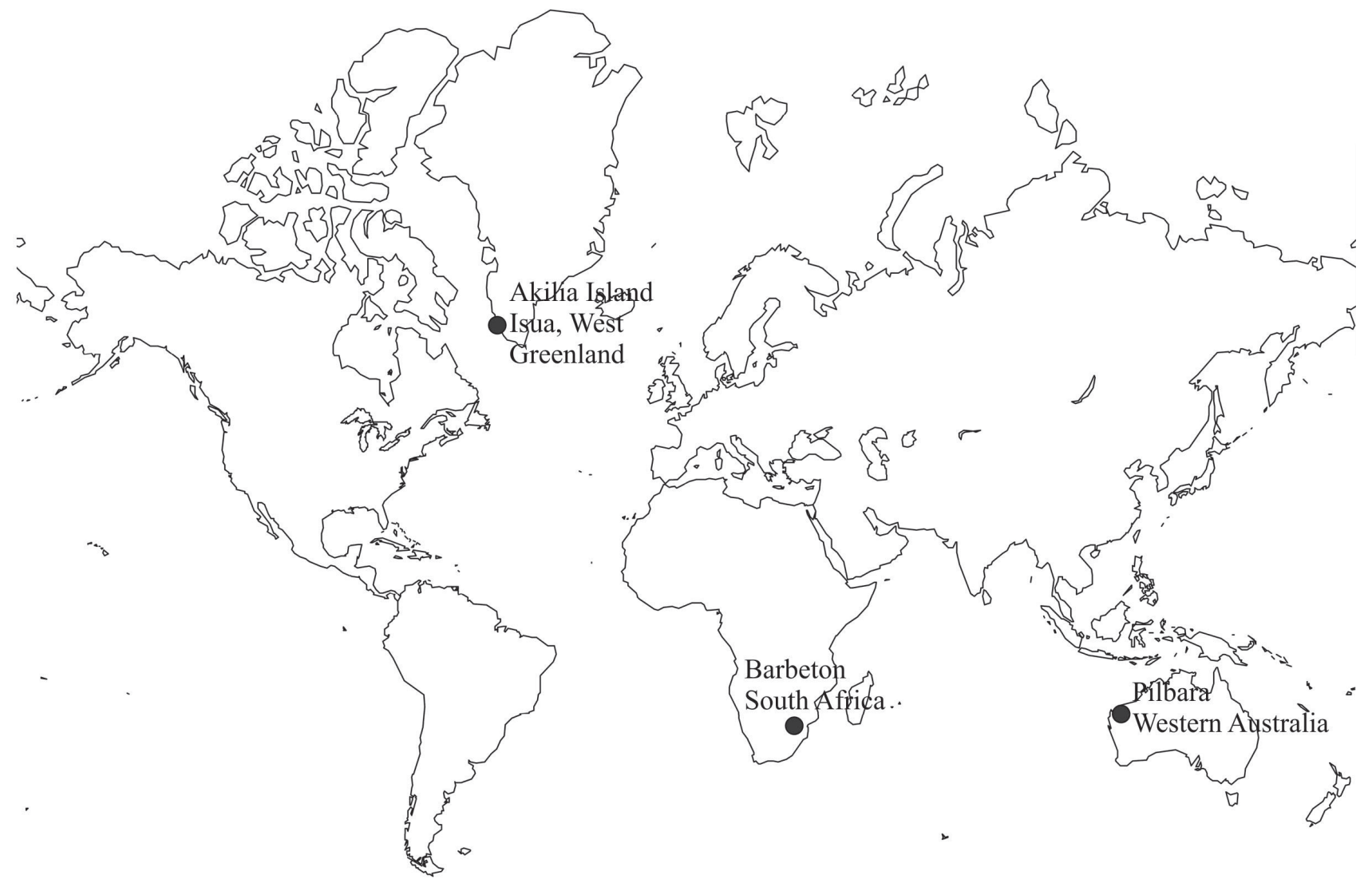

Figure 1. Location of the three sites with Eoarchean (Isua and Akilia Island, Greenland) and Paleoarchean (Pilbara, Australia and Barberton, Africa) crust rocks. 
crystallization or recrystallization age of the apatite from Akilia was $1750 \mathrm{Ma}$, and this does not correspond with the age of mafic ultramafic gneiss from the region (Whitehouse et al., 2009). The problem is that the rocks on Akilia present a high grade of metamorphism, which masks and hinders the identification of putative microfossils; even more, this metamorphism could have destroyed any possible fossil remains (Wacey et al., 2008a).

Ambient Inclusion Trails (AIT) have been suggested as potential biosignatures of putative microbials in Archean rocks. The use of AIT as biosignatures was studied in NE grains from Pilbara Craton (3460 Ma), Western Australia (Figure 1) (Wacey et al., 2008b). The results were not conclusive since the authors admitted that although their data were consistent with a biogenic origin, an inorganic origin could not be excluded. AITs are also problematic because their formation has not been rigorously studied and they are susceptible to contamination by modern fluid migration (Wacey et al., 2008b). Sandstone rocks have received less attention in the search for ancient life due to their low fossil preservation potential (Wacey et al., 2008b).

Microbially induced sedimentary structures (MISS) are another kind of biosignature feature. MISS are the result of interaction between biotic and physical processes: the sedimentary dynamic (Noffke, 2007). Noffke et al. (2003, 2006) and Noffke (2007) have recorded the presence of MISS in Archean sandstone from South Africa. Their results indicate the presence of photoautotrophic microbial mats in tidal environments in Moodies Group (3200 Ma) (Noffke et al., 2006; Noffke, 2007) and Pongola and Witwatersrand Supergroups (2900 Ma) (Noffke et al., 2003; Noffke, 2007).

Given the fact that most of the studies have been done on sedimentary rocks, an innovation in the search for the planet's earliest life was performed by Banerjee and coworkers (2006) when they decided to study subaqueous volcanic rocks. Banerjee et al. (2006) identified the geochemical and isotopic signature of microbial ichnofossil structures in pillow lavas between 3400 to $3500 \mathrm{Ma}$ old. They identified microbial activity associated with seafloor hydrothermal alteration at Barberton Greenstone Belt, South Africa (Figure 1). This finding represented the oldest evidence of microbial activity. Recently the age of this biosignature was rejected after the filamentous microstructure was dated with $\mathrm{U}-\mathrm{Pb}$, assigning an age of $2800 \mathrm{Ma}$ and considering it as an intrusion (this implies that the biosignature evidence is younger than the rock that contains it); the biogenicity of trace fossils was also questioned (Grosch and McLoughlin, 2014).

There is a marked lack of reports about chemical fossils from the Paleoarchean age. The oldest chemical fossils discovered, corresponding to the Neoarchean (2800 $2500 \mathrm{Ma}$ ), are hopanes and 2-methylhopanes, recovered in bitumens extracted from shales of the Fortescue and Hamersley Groups (2700 to $2500 \mathrm{Ma}$ ), Pilbara, Western Australia. This finding confirms the presence of bacteria and indicates the importance of cyanobacteria as primary producers during the Neoarchean age (Brocks et al., 2003). Meanwhile, in South Africa, in the Transvaal Supergroup sediments (2670 to $2460 \mathrm{Ma}$ ), hopanes of a bacterial origin were recovered, along with steranes of a eukaryotic origin. These chemical fossils support the presence of bacterial and eukaryotic life, as well as photosynthetic processes, during the Archean (Waldbauer et al., 2009).

Of course, considering the fact that the oldest rocks on Earth correspond to crustal rocks with intense metamorphism, it is necessary to determine the degree of metamorphism that can obliterate or erase the signs of biosignatures (Brasier et al., 2005).

\section{Paleoarchean (3600 - 3200 Ma) microfossil record}

The absence of rock records of the Earth's first 500 Ma prevents anything more than speculations about this time period, especially since the Hadean Eon (4500 $4000 \mathrm{Ma}$ ) is only known by detrital zircons (O'Neil et al., 2008; Harrison, 2009; Iizuka et al., 2009). The Archean Eon comprises the period between 4000 to $2500 \mathrm{Ma}$ and is divided into four eras: Eoarchean $(4000-3600 \mathrm{Ma})$, Paleoarchean (3600 - $3200 \mathrm{Ma})$, Mesoarchean (3200 - 2800 $\mathrm{Ma})$ and Neoarchean (2800 - $2500 \mathrm{Ma})$ (ICS, 2013).

The identification of the earliest life signatures is made difficult by the fact that the oldest crustal rocks from the Paleoarchean Era have been destroyed. In addition, only a few localities with rocks of such antiquity are known. Paleoarchean rocks are located in the Pilbara greenstone belts in northwestern Australia and the Barberton greenstone belts in eastern South Africa (Westall, 2005; Schopf, 2006) (Figure 1).

Although many criteria have been proposed, in regard to the Archean record, to recognize true microfossils from dubious ones (in the sense of Schopf, 2006) or pseudofossils (Schopf, 1992; Altermann and Kazmierczak, 2003; Schopf et al., 2010), it can still be very difficult to distinguish one from the other. In fact, many ancient records of life are subject to continuous controversies. Some "microfossils" recorded from the Paleoarchean before 1983 are now considered controversial and categorized as dubious or non-fossils (Schopf and Walter, 1983).

The Archean (3800 - 2500 Ma) fossil record is very poorly preserved in comparison with the Proterozoic (2500 - $540 \mathrm{Ma}$ ) (Brasier et al., 2005), and it is very difficult to separate the biotical simple forms and the abiotical complex structures of this eon (Oehler et al., 2008).

Poor preservation of Archean microfossils has been attributed, on the one hand, to a low potential for chert conservation and to the presence of volcanogenic or hydrothermal activity (Brasier et al., 2005). Stromatolitic structures are more common in the Archean. Nonetheless, preserved fossils are rarely present; consequently, it can be very difficult to prove that all the stromatolites reported have an undoubtedly biogenic origin (Schopf et al., 2007). 
A recent review of the nature and study of the stromatolitic record was performed by Riding (2011).

A very complete review about Archean life has also been done by Schopf (2006) and Schopf et al. (2007); since then, new reports have been added (e.g. Allwood et al., 2007; Wacey et al., 2011), and some of the microfossils reported before 2006 actually are considered to be controversial or non-biological in origin (e.g. the filamentous fossil bacteria discovered in Mount Ada Basalt, Warrawoona Group (3500 Ma) (Awramik et al., 1983) and the microbial carbonates of biological origin discovered in the Dresser Formation, Warrawoona Group $3490 \mathrm{Ma}$ (Van Kranendonk et al., 2003).

Microfossils like those discovered in the Apex Chert (3465 Ma), Warrawoona Group in Australia, and in the Fig Tree Group of the Barberton Greenstone Belts (BGB) in South Africa (3500 to $3300 \mathrm{Ma}$ ) were long considered to be classic examples of ancient life. Both records, however, have been heavily questioned and reevaluated and, finally, the biological origins of the microstructures were discarded at the beginning of the $21^{\text {th }}$ century (Schopf and Walter, 1983; Altermann, 2001; Brasier et al., 2002, 2005).

Australia's Apex Chert was considered to be the oldest bacteria fossil record (Schopf and Packer, 1987), but this interpretation did not fit the standard evolutionary history (Brasier et al., 2002, 2005). Nowadays, this record has been reinterpreted as belonging to a non-biogenic structure. Although the presence of microfossils has been rejected, it is accepted that the presence of carbonaceous material in the matrix around the fossil-like structures is consistent with microbial life and is considered, at present, to be evidence of early life (Marshall et al., 2011).

The first recognized true record of biosedimentation and the oldest Archean life was reported at the Strelley Pool Chert, Pilbara Craton (3430 Ma) in northwestern Australia. This formation resulted from the remains of an ancient microbial mat of a stromatolitic platform (Allwood et al., 2006, 2007). The biogeochemistry of this organosedimentary structure was studied by measuring sulfur isotopes as evidence of microbial metabolism (Brontognali et al., 2012). In addition, microstructures of biological affinity associated with pyrite and related to a sulphur-based metabolism under anaerobic conditions were reported at the Strelley Pool Formation (3400 Ma) (Wacey et al., 2011). At Dixon Island Formation (3200 Ma), Cleaverville Group, Pilbara, the presence of filamentous bacteria-like microfossil preserved in black chert has also been reported, this community probably developed in a low temperature hydrothermal vent system (Kiyokawa et al., 2006).

The oldest microfossils from South Africa were reported from the Onverwacht Group and the Fig Tree Group of BGB (e.g. Barghoorn and Schopf, 1966; Engel et al., 1968; Muir and Hall, 1974). These reports correspond to the Theespruit Formation (3544 - $3547 \mathrm{Ma}$ ), the Hooggenoeg Formation $(3472-3445 \mathrm{Ma})$ and the Kromberg Formation $(3416-3334 \mathrm{Ma})$ in the Onverwacht Group, and the
Swartkoppie Formation (3260 - $3230 \mathrm{Ma})$ in the Fig Tree Group (Altermann, 2001). Some previous reports from these Groups were criticized before and their biological origins were rejected, meaning they were classified as nonfossils or with dubious fossil content (Schopf and Walter, 1983; Altermann, 2001). Nevertheless, Altermann (2001) considers nine of the reports in South Africa as authentic microfossil occurrences dated from the Archean.

In the Onverwacht Group (3300 - $3500 \mathrm{Ma})$, probable biogenic structures were identified, resembling coccoid and bacillary bacteria in sediments with a probable hydrothermal nature (Westall et al., 2001). Although Altermann (2001) considered some interpretations found in Westall et al. (2001) as equivocal, the author recognized coccoid bacteria as true microfossils. The records considered to be true microfossils include: those found at the BGB in the Onverwacht Formation $(3260-3230 \mathrm{Ma})$, which correspond to filamentous microfossils interpreted as bacterial structures (Walsh and Lowe, 1985), and those found in the Kromberg Formation (3259 Ma), which are spheroidal and ellipsoidal structures resembling coccoidal bacteria microbial activity and which were discovered in chert with rare filamentous microfossils (Walsh, 1992).

Also in South Africa but in the Moodies Group, BGB (3200 Ma), in a shallow marine oldest siliciclastic (siltstones and shales) deposits on Earth, the presence of biologic carbonaceous microstructures has been reported. The biologic origins of the microstructures have been supported by petrographic, morphologic, geochemical, taphonomic and geologic data (Javaux et al., 2010).

A brief summary of the principal events related to the first evidence of life in the Hadean and the Lower Archean is shown in Figure 2.

\section{Conclusions remarks}

The study of the origin of life is complex, involving multiple disciplines including biology, astrochemistry, geochemistry, biochemistry, geomicrobiology, paleontology, and molecular biology, among others. A common problem is that specialists in these fields still consider only the isolated data of their own fields and fail to consider other disciplines as ripe for addressing the problem of the origin of life. Due to the lack of an ancient fossil record, paleontology is an important discipline that happens to be commonly obviated.

In paleontology, the extreme complexity of the oldest known fossils makes it difficult to consider them as the earliest existing. However, a chance still remains to sample the oldest actual fossil. In order to do this, outcrops of the oldest rock in non-sedimentary shallow environments must be reevaluated in light of new technologies and available techniques.

The use of technology such as SEM, transmission electron microscopy, high-resolution laser Raman spectroscopy, energy-dispersive x-ray spectroscopy, 


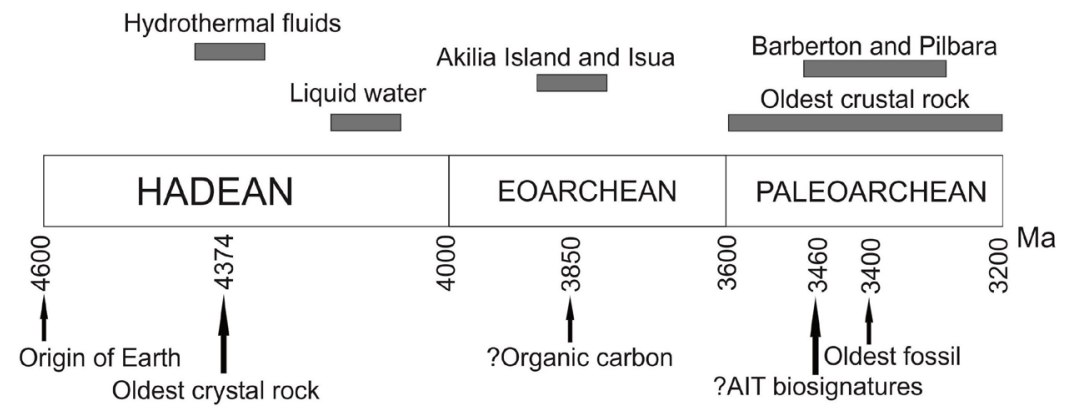

Figure 2. Brief summary of principal events in the Early Earth highlighting the evidence of life inferred by rocks and fossil record.

geochemical techniques, isotopic dating, secondary ion mass spectrometry (SIMS) and high-resolution secondary ion mass spectrometry (NanoSIMS), combined with detailed field and petrographic mapping, will together result in a better, newer interpretation and characterization of Archean microfossils and microstructures in the fossil record. This will help provide new clues for dating the existence of living beings more accurately and will give a better idea about when the origin of life was accomplished.

\section{Acknowledgements}

We thank CONACYT for the 168579 grant.

\section{References}

Allwood, A.C., Walter, M.R., Kamber, B.S., Marshall, C.P., Burch, I.W., 2006, Stromatolite reef from the Early Archean era of Australia: Nature, 441, 714-718.

Allwood, A.C., Walter, M.R., Burch, I.W., Kamber, B.S., 2007, 3.43 billion-year-old stromatolite reef from the Pilbara Craton of Western Australia: Ecosystem-scale insights to early life on Earth: Precambrian Research, 158, 198-227.

Altermann, W., 2001, The oldest fossils of Africa-a brief reappraisal of reports from the Archean: Journal of African Earth Sciences, 33, 427-436.

Altermann, W., Kazmierczak, J., 2003, Archean microfossils: a reappraisal of early life on Earth: Research in Microbiology, 154, 611-617.

Antcliffe, J., McLoughlin, N., 2008, Deciphering fossil evidence for the origin of life and the origin of animals: Common challenges in different worlds, in Seckbach, J., Walsh, M. (eds.), Deciphering Fossil Evidence for the Origin of Life and the Origin of Animals: Neetherland, Springer, 211-229.

Awramik, S.M., Grey, K., 2005, Stromatolites: Biogenicity, Biosignatures, and Bioconfusion. Astrobiology and Planetary Missions: Proceedings of SPIE, 5906, 1-9.

Awramik, S.M., Schopf, J.W., Walter, M.R., 1983, Filamentous fossil bacteria from the Archean of Western Australia: Precambrian Research, 20, 357-374.

Banerjee, N.R., Furnes, H., Muehlenbachs, K.M., Staudigel, H., de Wit, M., 2006, Preservation of $\sim 3.4-3.5$ Ga microbial biomarkers in pillow lavas and hyaloclastites from the Barberton Greenstone Belt, South Africa: Earth and Planetary Science Letters, 241, 707-722.

Barghoorn, E.S., Schopf, J.W., 1966, Microorganisms three billion years old from the Precambrian of South Africa: Science, 152, 758-760.

Battistuzzi, F.U., Hedges, S.B., 2009, A major clade of prokaryotes with ancient adaptations to life on land: Molecular Biology Evolution, $26,335-343$.
Boetius, A., 2005, Lost City Life: Science, 307, 1420-1422.

Brasier, M.D., Green, O.R., Jephcoat, P., Kleppe, A.K., Van Kranendonk, M.J., Lindsay, J.F., Steele, A., Grassineau, N.V., 2002, Questioning the evidence for Earth's oldest fossils: Nature, 416, 76-81.

Brasier, M.D., Green, O.R., Lindsay, J.F., McLoughlin, N., Steele A., Stoakes, C., 2005, Critical testing of Earth's oldest putative fossil assemblage from the $\sim 3.5 \mathrm{Ga}$ Apex chert, Chinaman Creek, Western Australia: Precambrian Research, 140, 55-102.

Brocks, J.J., Buick, R., Summons, R.E., Logan, G.A., 2003, A reconstruction of Archean biological diversity based on molecular fossils from the 2.78 to 2.45 billion-year-old Mount Bruce Supergroup, Hamersley Basin, Western Australia: Geochimica et Cosmochimica Acta, 67, 4321-4335.

Brontognali, T.R.R., Allwood, A.C., Fischer, W.W., Gritzinger, J.P., Summons, R.E., Eiler, J.M., 2012, Sulfur isotopes of organic matter preserved in 3.45-billion-year-old stromatolites reveal microbial metabolism: Proceedings of the National Academy of Science, 109, 15146-15151.

Dauphas, N., Robert, F., Marty, B., 2000, The late asteroidal and cometary bombardment of Earth as recorded in water deuterium to protium ratio: Icarus, 148, 508-512.

Dauphas, N., van Zuilen, M., Wadhwa, M., Davis, A.M., Marty, B., Janney, P.E., 2004, Clues from Fe isotope variations on the origins of early Archean BIFs from Greenland: Science, 306, 2077-2080.

Dauphas, N., van Zuilen, M., Busigny, V., Lepland, A., Wadhwa, M., Janney, P.E., 2007, Iron isotope, major and trace element characterization of early Archean supracrustal rocks from SW Greenland: protolith identification and metamorphic overprint: Geochimica et Cosmochimica Acta, 71, 4745-4770.

de Ronde, C.E.J., Ebbesen, T., 1996, 3.2 billion years of organic compound formation near seafloor hot springs: Geology, 24, 791-794.

Edwards, H.G.M., Hutchinson, I.B., Ingley, R., Waltham, N.R., Beardsley, S., Dowson, S., Woodward, S., 2011, The search for signatures of early life on Mars: Raman spectroscopy and the Exomars mission: Spectroscopy Europe, 23, 6-15.

Engel, A.E.J., Nagy, B., Nagy, L.A., Engel, C.G., Kremp, G.O.W., Drew, C.M., 1968, Algal-like forms in Onverwacht Series, South Africa: oldest recognized life-like forms on Earth: Science, 161, 1005-1008.

Farquhar, J., Wing, B.A., 2003, Multiple sulfur isotopes and the evolution of the atmosphere: Earth and Planetary Science Letters, 213, 1-13.

Fedo, C.M., Whitehouse, M.J., 2002, Metasomatic origin of quartzpyroxene rock, Akilia, Greenland, and Implications for Earth's earliest life: Science, 296, 1448-1452.

Grassineau, N.V., Abell, P., Appel, P.W.U., Lowry, D., Nisbet, E.G., 2006, Early life signatures in sulfur and carbon isotopes from Isua, Barberton, Wabigoon (Steep Rock), and Belingwe Greenstone Belts (3.8 to $2.7 \mathrm{Ga}$ ): Geological Society of America Memoirs, 198, 33-52.

Grosch, E.G., McLoughlin, N., 2014, Reassessing the biogenicity of Earth's oldest trace fossil with implications for biosignatures in the search for early life: Proceedings of the National Academy of Sciences of the United States of America, 111, 8380-8385.

Grotzinger, J.P., Kasting, J.F., 1993, New constraints on Precambrian ocean composition: Journal of Geology, 101, 235-243. 
Harrison, T.M., 2009, The Hadean Crust: Evidence from > 4 Ga Zircons: Annual Review of Earth and Planetary Sciences, 37, 479-505.

Holland, H.D., 1984, The chemical evolution of the atmosphere and oceans: Princeton New Jersey, Princeton University Press, $582 \mathrm{p}$.

Iizuka, T., Komiya, T., Johnson, S.P., Kon, Y., Maruyama, S., Hirata, T., 2009, Reworking of Hadean crust in the Acasta gneisses, northwestern Canada: Evidence from in-situ Lu-Hf isotope analysis of zircon: Chemical Geology, 259, 230-239.

International Commission on Stratigraphy (ICS), 2013, International chronostratigraphic chart: available at: $<\mathrm{http}: / / \mathrm{www}$. stratigraphy.org/ ICSchart/ChronostratChart2013-01.jpg>, accessed March 312014.

Javaux, E.J., Marshall, C.P., Bekker, A., 2010, Organic-walled microfossils in 3.2-billion-year-old shallow-marine siliciclastic deposits: Nature, 463, 934-938.

Kempe, S., Degens, E.T., 1985, An early soda ocean?: Chemical Geology, $5,95-108$.

Kiyokawa, S., Ito, T., Ikehara, M., Kitajima, F., 2006, Middle Archean volcano-hydrothermal sequence: bacterial microfossil-bearing 3.2-Ga Dixon Island Formation, coastal Pilbara terrane, Australia: Geological Society of America Bulletin, 118, 3-22.

Lane, N., Allen, J.F., Martin, W., 2010, How did LUCA make a living? Chemiosmosis in the origin of life: Bioessays, 32, 271-280.

Lazcano, A., Miller, S.L., 1994, How long did it take for life to begin and evolve to cyanobacteria?: Journal of Molecular Evolution, $39,546-54$.

Lepland, A., van Zuilen, M.A., Arrhenius, G., Whitehouse, M.J., Fedo, C.M., 2005, Questioning the evidence for Earth's earliest life-Akilia revisited: Geology, 33, 77-79.

Marshall, C.P., Emry, J.R., Marshall, A.O, 2011, Haematite pseudomicrofossils present in the 3.5-billion-year-old Apex Chert: Nature, 4, 240-243.

McKeegan, K.D., Kudryavtsev, A.V., Schopf, J.W., 2007, Raman and ion microscopic imagery of graphitic inclusions in apatite from older than 3830 Ma Akilia supracrustal rocks, west Greenland: Geology, $35,591-594$

Mojzsis, S.J., Harrison, T.M., 2000, Vestiges of a beginning: clues to the emergent biosphere recorded in the oldest know sedimentary rocks: Geological Society of America Today, 10, 1-7.

Mojzsis, S.J., Arrhenius, G., Mckeegan, K.D., Harrison, T.M., Nutman, A.P., Friend, C.R.L., 1996, Evidence for life on Earth before 3,800 million years ago: Nature, 384, 55-59.

Muir, M.D., Hall, D.O., 1974, Diverse microfossils in Precambrian Onverwacht Group rocks of South Africa: Nature, 252, 476-478.

Nemchin, A.A., Whitehouse, M.J., Menneken, M., Geisler, T., Pidgeon, R.T., Wilde, S.A., 2008, A light carbon reservoir recorded in zirconhosted diamond from the Jack Hills: Nature, 454, 92-95.

Noffke, N., 2007, Microbially induced sedimentary structures in Archean sandstones: A new window into early life: Gondwana Research, $11,336-342$.

Noffke, N., Hazen, R., Nhleko, N., 2003, Earth's earliest microbial mats in a siliciclastic marine environment (Mozaan Group, $2.9 \mathrm{Ga}$, South Africa): Geology, 31, 673-676.

Noffke, N., Hazen, R., Eriksson, K., Simpson, E., 2006, A new window into early life: microbial mats in a siliciclastic early Archean tidal flat (3.2 Ga Moodies Group, South Africa): Geology, 34, 253-256.

Nutman A.P., Friend C.R.L., 2006, Petrography and geochemistry of apatites in banded iron formation, Akilia, W. Greenland: Consequences for oldest life evidence: Precambrian Research, 147, 100-106.

Oehler, D.Z., Robert, F., Mostefaoui, S., Meibom, A., Selo, M., McKay, D.S., Gibson, E.K., 2008, NanoSIMS opens a new window for deciphering organic matter in terrestrial and extraterrestrial samples, in Seckbach, J., Walsh, M. (eds.), Deciphering Fossil Evidence for the Origin of Life and the Origin of Animals: Neetherland, Springer, 3-24.

O’Neil, J., Carlson, R.W., Francis, D., Stevenson, R.K., 2008, Neodymiun-142 Evidence for Hadean Mafic Crust: Science, 321, 1828-1831.
Philippot, P., Van Zuilen, M., Lepot, K., Thomazo, C., Farquhar, J., Van Kranendon, M.J., 2007, Early Archaean microorganisms preferred elemental sulfur, not sulfate: Science, 317, 1534-1537.

Pinti, D.L., 2005, The Origin and Evolution of the Oceans: Lectures in Astrobiology, 1, 83-112.

Riding, R., 2011, The Nature of Stromatolites: 3500 Million Years of History and a Century of Research. Advances in Stromatolite Geobiology: Lecture Notes in Earth Sciences, 131, 29-74

Russell, M.J., Hall, A., 1997, The emergence of life from iron monosulphide bubbles at a submarine hydrothermal redox and $\mathrm{pH}$ front: Journal of Geological Society of London, 154, 377-402.

Schopf, W.J., 1992, The oldest fossils and what they mean, in Schopf, J.W. (ed.), Major Events in the History of Life: Boston, Jones and Bartlett Publishers, 29-63,

Schopf, J.W., 2006, Fossil evidence of Archaean life: Philosophical Transactions of the Royal Society B, 361, 869-885.

Schopf, J.W., Packer, B.M., 1987, Early Archean (3.3-billion to 3.5-billionyear-old) microfossils from Warrawoona Group, Australia: Science, 237, 70-73.

Schopf, J.W., Walter, M.R., 1983, Archean microfossils: new evidence of ancient microbes, in Schopf, J.W. (ed.), Earth's earliest biosphere, Princeton, Princeton Univ. Press, 214-239.

Schopf, J.W., Kudryavtsev, A.B., Czaja, A.D., Tripathi, A.B., 2007, Evidence of Archean life: Stromatolites and microfossils: Precambrian Research, 158, 141-155.

Schopf, J.W., Kudryavtsev, A.B., Sugitani, K., Waltere, M.R., 2010, Precambrian microbe-like pseudofossils: A promising solution to the problem: Precambrian Research, 179, 191-205.

Sharma, N.S., 2005, Molecular cellular biology: New Delhi, Mittal Publications, $288 \mathrm{p}$.

Steele, A., Beaty, D.W., Amend, J., Anderson, R., Beegle, L., Benning, L., Bhattacharya, J., Blake, D., Brinckerhoff, W., Biddle, J., Cady, S., Conrad, P., Lindsay, J., Mancinelli, R., Mungas, G., Mustard, J., Oxnevad, K., Toporski, J., Waite, H., 2006, The Astrobiology Field Laboratory: JPL Document Review Services (Reference \#CL\#06-3307), Mars Exploration Program Analysis Group (MEPAG): September 2006, online: <mepag.jpl.nasa.gov/reports/ AFL SSG WHITE PAPER v3.doc>last accessed March 312014.

Touret, J.L.R., 2003, Remnants of early Archaean hydrothermal methane and brines in pillow-breccia from the Isua Greenstone Belt, West Greenland: Precambrian Research, 126, 219-233.

Valley, J.W., Cavosie, A.J., Ushikubo, T., Reinhard, D.A., Lawrence, D.F., Larson, D.J., Clifton, P.H., Kelly, T.F., Wilde, S.A., Moser, D.E., Spicuzza, M.J., 2014, Hadean age for a post-magma-ocean zircon confirmed by atom-probe tomography: Nature, 7, 219-22.

Van Kranendonk, M.J., Webb, G.E., Kamber, B.S., 2003, Geological and trace element evidence for a marine sedimentary environment of deposition and biogenicity of $3.45 \mathrm{Ga}$ stromatolitic carbonates in the Pilbara Craton, and support for a reducing Archaean ocean: Geobiology, 1, 91-108.

Wacey, D., McLoughlin, N., Brasier, M.D., 2008a, Looking through windows onto the earliest history of life on Earth and Mars, in Seckbach, J., Walsh, M. (eds.), From fossils to Astrobiology, Cellular Origin, Life in Extreme Habitats and Astrobiology, 12, Springer, 41-68.

Wacey, D., Kilburn, M.R., McLoughlin, N., Parnell, J., Stoakes, C.A., Grovenor, C.R.M., Brasier, M.D., 2008b, Use of NanoSIMS in the search for early life on Earth: ambient inclusion trails in a $3400 \mathrm{Ma}$ sandstone: Journal of the Geological Society, 165, 43-53.

Wacey, D., Saunders, M., Cliff, J., Brasier, M.D., 2011, Microfossils of sulphur-metabolizing cells in 3.4-billion-year-old rocks of Western Australia: Nature, 4, 698-702.

Waldbauer, J.R., Sherman, L.S., Sumner, D.Y., Summons, R.E., 2009, Late Archean molecular fossils from the Transvaal Supergroup record the antiquity of microbial diversity and aerobiosis: Precambrian Research, 169, 28-47.

Wächtershäuser, G., 1992, Groundworks for an evolutionary biochemistry: the iron-sulfur world: Progress in Biophysics \& Molecular Biology, 
$58,85-201$

Walsh, M.M., 1992, Microfossils and possible microfossils from the Early Archean Onverwacht Group, Barberton mountain land, South Africa: Precambrian Research, 54, 271-293.

Walsh, M.M., Lowe, D.R., 1985, Filamentous microfossils from the 3500 Myr-old Onverwacht Group, Barberton Mountain Land, South Africa: Nature, 314, 530-532.

Westall, F., 2005, Early Life on Earth: The Ancient Fossil Record, in Burton, W.B. (ed.), Astrobiology: Future Perspectives, Astrophysics and Space Science Library: Netherlands, Springer, 287-316.

Westall, F., de Wit, M.J., Dann, J., van der Gaast, S., de Ronde, C.E.J., Gerneke, D., 2001, Early Archean fossil bacteria and biofilms in hydrothermally-influenced sediments from the Barberton Greenstone Belt, South Africa: Precambrian Research, 106, 93-116.
Whitehouse, M.J., Myers, J.S, Fedo, C.M., 2009, The Akilia Controversy: field, structural and geochronological evidence questions interpretations of $>3.8$ Ga life in SW Greenland: Journal of the Geological Society, 166, 335-348.

Wilde, S.A., Valley, J.W., Peck, W.H., Graham, C.M., 2001, Evidence from detrital zircons for the existence of continental crust and oceans on the Earth 4.4 Gyr ago: Nature, 409, 175-178.

Manuscript received: April 29, 2014

Corrected manuscript received: November 25, 2014

Manuscript accepted: January 5, 2015 